Quality Of Some Types Of Cakes And The Economical Value

\title{
Introduction
}

Cakes are eaten in different ways either spongy or butter type, different flavours as plain or filled with cream, chocolate or nuts. Or added fruit juice as mandarin juice and its peels for better and fresh flavour of cakes $^{(1)}$.

Cakes and cookies are found to be one of the ten foods and beverages are eaten as snacks by high school students ${ }^{(2)}$. Sugary starchy snacks including cakes were composed (21\%) among children snacks aged 2-11 yrs. ${ }^{(3)}$. Also cakes are considered nutritious snacks which are better eaten than those have empty calories which provide less than $5 \%$ of the recommended daily intakes of eight specified nutrients/ serving as soda or chewing gums ${ }^{(2)}$. Cakes also could fill the nutrient gaps in children from either missed or hurried meals help their minds and bodies function properly ${ }^{(4)}$. So it was recommended that for children aged 2-11 yrs. must have 4-6 meals/day ${ }^{(5)}$.

Khalafalla et al., (1991) ${ }^{(6)}$ indicated that cream used as topping for cake decoration after backing is considered a serious source of Staphylococcus. Packaging process is very important for improving the microbiological quality of bakery products lowers the incidence of contamination with $E$. coli and lower the level of moulds due to the hygienic factors applied in processing, handling and storage ${ }^{(7)}$.

So Food safety is very important to be considered as a major health concern for dietetic professionals because of the food-borne disease outbreaks and its causes as parasites, bacteria, viruses, bottle water and 


\section{Quality Of Some Types Of Cakes And The Economical Value}

variety of chemicals, ${ }^{(8 \& 9)}$. The vulnerable populations who are at risk from food-borne diseases and subsequent death are elderly over 65 years, pregnant women and children specially under five years. It is clear that the high hygienic standards are needed when providing meals to those vulnerable population ${ }^{(10 \& 11)}$.

The present study aiming for: Studying the quality of the five types of cakes available in Egyptian market and its economical values.

\section{MATERIALS AND METHODS}

\section{Sample collection.}

Five types of cakes were investigated as follow: (1) Home-Made (butter cake), (2) Local Commercial Packaged (powdered - vanilla), (3 \&4) Two Types of Local Commercial Packaged Cakes (ready to eat) and (5) one Imported Type Commercially Packaged (ready to eat). All ingredients and cake types were purchased from local market in Cairo, Egypt. Five samples from each commercial cake were purchased from different shops, same period and same commercial names. Cake Types 1 and 2 were baked in the nutrition laboratory according to the standard method of making cakes ${ }^{(12)}$. The five types of cakes, their contents and the economical values are shown in table (1).

\section{Nutritional analysis}

It was made for moisture, ash and the eight specified nutrients in The National Nutrition Institute, Cairo, Egypt according the Official Methods proposed by the Association of Official Analytical Chemists ${ }^{(13)}$. All 
Quality Of Some Types Of Cakes And The Economical Value nutrient values were compared with Recommended Dietary Allowances (14) and Dietary Reference Intakes, (DRI) ${ }^{(15)}$, for preschoolers (4-6 yrs) and schools age (7-11 yrs).

TABLE (1): DESCRITIVE DATA OF CAKE TYPES

\begin{tabular}{|c|c|c|c|c|c|c|c|}
\hline$z$ & \multicolumn{3}{|c|}{ Cake types } & $\begin{array}{c}\text { Net } \\
\text { weight/ } \\
\text { portion }\end{array}$ & $\begin{array}{l}\text { Price } \\
\text { E.P./ } \\
\text { portion }\end{array}$ & $\begin{array}{l}\text { Validity } \\
\text { / month }\end{array}$ & Contents \\
\hline 1 & 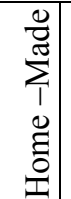 & \multicolumn{2}{|c|}{ Butter } & $50 \mathrm{gm}$ & 0.40 & & $\begin{array}{l}\text { refined flour, sucrose, } \\
\text { margarine, milk, egg, baking } \\
\text { powder and vanilla. }\end{array}$ \\
\hline 2 & & \multicolumn{2}{|c|}{$\begin{array}{l}\text { Local } \\
\text { Powdered } \\
\text { (Vanilla) }\end{array}$} & 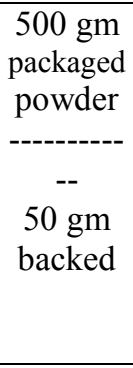 & 0.62 & $\begin{array}{c}9 \text { as a } \\
\text { powder }\end{array}$ & $\begin{array}{l}\text { refined wheat flour, sucrose, } \\
\text { vegetable oil, mono-calcium } \\
\text { phosphate, baking soda, } \\
\text { modified corn starch, dextrose, } \\
\text { artificial colour and flavour. } \\
\text { Added } 3 \text { eggs, } 3 / 4 \text { cup of water, } \\
1 / 2 \text { cup of butter (during } \\
\text { preparation as label } \\
\text { instructions). }\end{array}$ \\
\hline 3 & 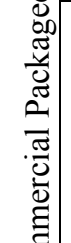 & \multirow{3}{*}{ 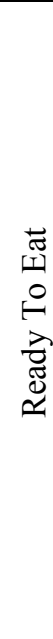 } & Local 1 & $40 \mathrm{gm}$ & 0.25 & (3) & $\begin{array}{l}\text { flour, sugar, starch, corn syrup, } \\
\text { sun flour oil, eggs, milk powder, } \\
\text { emulsifiers, lecithin, water, } \\
\text { sorbitol, glucose, potassium } \\
\text { sorbate, dextrose, backing } \\
\text { agents, coca powder }\end{array}$ \\
\hline 4 & రే & & Local 2 & $48 \mathrm{gm}$ & 0.50 & (3) & $\begin{array}{l}\text { Wheat starch, whole eggs, } \\
\text { liquid, hydrogenate vegetable } \\
\text { oil, sugar, stabilizer, sorbitol, } \\
\text { emulsifiers, raising agents } \\
\text { E450/E500. }\end{array}$ \\
\hline 5 & & & Imported & $42 \mathrm{gm}$ & 3.00 & (3) & $\begin{array}{l}\text { Cocao powder, plant oil, skim. } \\
\text { milk, sugar, refined flour, soya } \\
\text { powder, syrup, glucose, lemon } \\
\text { juice, ammonia carbonate, } \\
\text { emulsifier, salt, eggs. }\end{array}$ \\
\hline
\end{tabular}




\section{Quality Of Some Types Of Cakes And The Economical Value Bacteriological analysis}

Aerobic Plate Count (APC) and Total Fungi were determined using nutrient agar and fungi agar media were purchased from El-Gomheria Pharmaceutical Company Ameriea, Cairo, Egypt. The package integrity of each type container was checked prior the analysis. Care was taken to ensure that contamination of cakes from the outside did not happen from the package in types 3, 4 and 5 by swabbing of the outer package with 70 $\%$ alcohol carefully according to the hygienic precautions of the International Commission on Microbiological Specifications for Food (ICMSF) (16). All the bacteriological analysis were made in microbiological laboratory in the Faculty of Specific Education. Fifty samples were investigated and analyzed as representative of the five types of cakes (ten each). Sterile distilled water peptone was used to make serial dilution before plating according to (ICMSF) ${ }^{(16)}$. Petrifilm aerobic plate count for quantifying Aerobic Plate Counts (APC) were incubated for 48 hr at $35^{\circ} \mathrm{C} \pm 2{ }^{\circ} \mathrm{C}$, and colonies were counted. The aerobic plate counts present in the fresh samples were enumerated by spread and spiral plating triplicate samples onto nutrient agar media, identified and confirmed by establishing certain key morphological and biochemical characteristics. Fungi agar media was incubated for $72 \mathrm{hr}$ at $30^{\circ} \mathrm{C} \pm 2{ }^{\circ} \mathrm{C}$ and confirmed by establishing certain key morphological and biochemical characteristics were made ${ }^{(17)}$.

All data were statistically analyzed using ANOVA (Statistica 5.0). All significant differences were reported at the $95 \%$ level of confidence ( $\mathrm{P}$ $<0.05)^{(18)}$. 
Quality Of Some Types Of Cakes And The Economical Value

\section{Shelf life and Sensory Evaluation For Backed Cakes Types (1 \& 2).}

Cakes types $1 \& 2$ were baked twice in December and in May. After baking cakes they were left until cooled completely to be cut easily without waste. Three samples were taken from each type weighed, and put in plastic box.

Each sample was put as follow :-

a- At room temperature $\left(25^{\circ} \mathrm{C} \& 20^{\circ} \mathrm{C}\right)$.

b- Refrigerator shelf

c- In freezer.

All samples were sensory evaluated at 4, 8, 15, 20 30, 60 \&70 days. According the appearance, colour, smell, odour, tenderness, size, taste and flavour for quality of staying and overall acceptability ${ }^{(19 \& 20)}$. Using a panel of ten well trained from the staff of Nutrition and Food Science and in the Home Economics Dept., Faculty of Specific Education, Ain Shams University. They were instructing to give a score of a hedonic scale ranging from zero to five for each characteristic (like it very much, like it, acceptable, not acceptable and dislike). Mean value of cakes were subjected to statistical analysis using ANOVA and Least Significant Different test (LSD) at 0,05 level $^{(18)}$.

\section{Economical value:}

Each type of cakes was compared to: Its net weight/portion and its price in Egyptian currency (pound). 


\section{Quality Of Some Types Of Cakes And The Economical Value}

\section{RESULTS AND DISCUSSION}

\section{Nutritional assessment}

Concerning the nutritional values of the five types of cakes (table 2). It is clear that the highest protein value was found in type (1) home-made, which was $9.60 \mathrm{~g} \%$ protein. This results approximately agreed well with similar study which was applied in the National Nutrition Institute from Great Cairo (four regions) on different types of bakery products including (wheat cake, milk). Protein content was $(9.50 \mathrm{~g} \%)^{(21)}$.

Imported commercial packaged cake the most expensive type (5) was found to have a lower content of protein $(6.30 \mathrm{~g} \%)$ than other types (1, 2 and 4), while it has the highest content from energy, fat, zinc and calcium percentages were $(557.0 \mathrm{Kcal} \%),(54.50 \mathrm{gm} \%),(1.20 \mathrm{mg} \%)$ and $(278.0 \mathrm{mg} \%)$, respectively. These results were in contrast with other study reported that samples of cakes collected from great Cairo regions had $733.02 \mathrm{Kcal} \%, 9.1 \mathrm{~g} \%$ fat and $0.87 \mathrm{mg} \%$ zinc but there is not analysis for calcium $^{(21)}$.

A strange but a good result was obtained in the present study concerning the cheapest cake type (3) has the highest content of iron (4.90 $\mathrm{mg} \%$ ), followed by the imported type (3.30 mg\%)and then types $(2,1$ and $4)$, respectively. Other study stated that iron content was $1.48 \mathrm{mg} / 100 \mathrm{~g}^{(21)}$.

Vitamin A was also the highest value in the cheapest local commercial packaged type (4 and 3) which were $5768 \mathrm{IU} \%$ and 5127 IU\%, respectively, followed by the imported type (5) and then types ( 2 and 1), respectively. It is clear that all five types of cakes in the present study have 


\section{Quality Of Some Types Of Cakes And The Economical Value}

excellent percentages from vitamin A which is considered a health benefit for all age groups.

Comparing the nutritional values table (2) with the RDA, DRI ${ }^{(14,15)}$. The portion size $(50 \mathrm{~g})$ from baked cake type (1) or type (3) could provide with $6.4 \%$ or $4.5 \% \mathrm{Kcal}$ of the daily energy needed for a pre-school child ( $4-6$ yrs $)$ or an adolescent $(7-11$ yrs $)$, respectively. Also type (1) could provide with $20 \%$ and $10 \% \mathrm{~g}$ protein required for the same age groups. The cheapest type (3) of the local commercial packaged cake could provide with $49 \%$ and $32.7 \mathrm{mg} \%$ of iron for the same age groups, respectively. Iron content in one piece type (3) was higher than iron which was taken by pre-schoolars [(2-4, 4-6 yrs) and 7-11 yrs] children from three snacks/day for each child which were $32.3 \%, 26.5 \%$ and $26.9 \%$ respectively from iron/day in the three age groups as stated in similar results ${ }^{(3)}$.

TABLE (2): PERECENTAGES OF NUTRIENT ANALYSIS OF CAKE TYPES .

\begin{tabular}{|l|c|c|c|c|c|}
\hline \multirow{2}{*}{$\begin{array}{l}\text { Nutrient content } \\
\%\end{array}$} & Home Made & \multicolumn{4}{c|}{ Commercial Packaged } \\
\cline { 2 - 6 } & Butter & Local & \multicolumn{3}{c|}{ Ready To Eat } \\
\cline { 5 - 6 } & 1 & Powdered & Local & Local & Imported \\
& & 2 & 3 & 4 & 5 \\
\hline Moisture gm & 26.60 & 27.70 & 15.80 & 16.40 & 2.20 \\
\hline Protein gm & 9.60 & 8.20 & 9.50 & 5.53 & 6.30 \\
\hline Fat gm & 15.90 & 11.40 & 21.10 & 14.10 & 54.50 \\
\hline Ash gm & 0.90 & 1.40 & 0.70 & 1.0 & 1.80 \\
\hline Carbohydrate gm & 46.98 & 51.26 & 52.90 & 62.97 & 55.20 \\
(by different) & & & & & \\
\hline Energy Kcal. & 370.0 & 341.0 & 440 & 401 & 557.0 \\
\hline Vitamin. A (IU) & 3037 & 4363 & 5127 & 5768 & 5124 \\
\hline Iron mg & 1.40 & 1.45 & 4.90 & 1.30 & 3.30 \\
\hline Zinc mg & 0.90 & 0.94 & 0.92 & 0.92 & 1.20 \\
\hline Calcium mg & 51.0 & 47.7 & 109.0 & 66.5 & 278.0 \\
\hline
\end{tabular}




\section{Quality Of Some Types Of Cakes And The Economical Value}

Concerning zinc, it was found that types [(1, (3\&4)] could provide with $9 \%, 9.2 \% \mathrm{mg}$ zinc for preschoolars (4-6 yrs) and (7 - $10 \mathrm{yrs})$ children, from the DRI, (2000), respectively. It's clear from table (2) that all types of cakes could provide with some amount of the daily recommended nutrients as protein, vitamin $\mathrm{A}$, iron, zinc, calcium and energy either in young or old age it could fill the nutrient gaps between meals. Children were recommended to take from 4-6 meals per day ${ }^{(5)}$.

\section{Microbiological assessment}

After all fifty samples which were made examined properly and assessed for the mean aerobic plate count (APC), total count of fungi and the incidences of coliforms bacteria in the five cake types tables $(3,4 \&$ 5)., All the five types of cakes were of satisfactory bacteriological quality (table 3). They had total aerobic plate counts (APC) lower than the Recommended Safety Limit of $\left(10^{4} \mathrm{CFU} \mathrm{g}^{-1}\right)$ proposed by the International Dietetics Association of the European Community (IDAEC) and the Egyptian Organization for Standardization and Quality Control, ${ }^{(22}$ \& 23). There were approximately no difference between results obtained with nutrient agar and those obtained with milk agar at $(\mathrm{p}<0.05)$,(Table 3$)$.

Coliforms were not detected in any of 1-gram cake samples of the five cake types examined. This result was consistent with almost all the recommendations which postulate that cake should be free from coliform bacteria. The present result is completely disagree with many studies $(24,25$ \& 26) who reported that coliforms bacteria were found in most of bakery products.Moreover, the current results for coliforms bacteria is completely 


\section{Quality Of Some Types Of Cakes And The Economical Value}

disagree with similar study stated that coliforms bacteria were isolated from $20 \%$ of unpackaged cakes with total count of $(11 \text { cell/gram })^{(26)}$. The present result is different due to the difference in environment and the level of hygienic precautions are made for packaging process during industry stages, or during baking as in types $\left(\begin{array}{lll}1 & \& & 2\end{array}\right)$ in nutrition laboratory.

TABLE (3): TOTAL AEROBIC PLATE COUNTS (APC) EXHIBITED BY 50 SAMPLES OF FIVE CAKE TYPES

\begin{tabular}{|c|c|c|c|c|c|c|c|c|}
\hline \multirow[t]{2}{*}{ No. } & \multirow{2}{*}{$\begin{array}{l}\text { Types } \\
\text { of } \\
\text { cakes }\end{array}$} & \multirow[t]{2}{*}{ Samples } & \multirow[t]{2}{*}{$\begin{array}{c}\text { No } \\
\text { samples }\end{array}$} & \multicolumn{4}{|c|}{$\begin{array}{l}\text { No. units with total aerobic count } \\
\left(\log \mathrm{CFU} \mathrm{g}^{-1}\right) \text { in the range }\end{array}$} & \multirow{2}{*}{$\begin{array}{c}\begin{array}{c}\text { Total aerobic } \\
\text { count } \\
\left(\log \mathrm{CFU} \mathrm{g}^{-1}\right)\end{array} \\
\text { Mean }\end{array}$} \\
\hline & & & & $<1.0$ & $\leq 1.0-$ & & $0-4.0$ & \\
\hline \multirow[t]{2}{*}{1} & \multirow{2}{*}{ 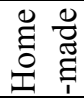 } & \multirow[t]{2}{*}{ Butter } & 5 & - & 2 & 1 & 2 & $1.0 \times 10^{4 \mathrm{a}}$ \\
\hline & & & 5 & 1 & 1 & 2 & 1 & $1.3 \times 10^{4^{*} \mathrm{a}}$ \\
\hline \multirow[t]{2}{*}{2} & \multirow{8}{*}{ 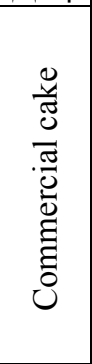 } & Local & 5 & - & 1 & 2 & 2 & $7.0 \times 10^{4 c}$ \\
\hline & & Powder & 5 & 1 & 1 & 1 & 2 & $6.8 \times 10^{4 * c}$ \\
\hline \multirow[t]{2}{*}{3} & & $\$$ Local 1 & 5 & 1 & 1 & 2 & 1 & $2.5 \times 10^{4 b}$ \\
\hline & & 4 & 5 & - & 1 & 2 & 2 & $2.2 \times 10^{4 * b}$ \\
\hline \multirow[t]{2}{*}{4} & & Local 2 & 5 & 2 & 1 & 1 & 1 & $2.0 \times 10^{4 b}$ \\
\hline & & $\Rightarrow$ & 5 & 1 & 1 & 1 & 2 & $2.5 \times 10^{4 * b}$ \\
\hline \multirow[t]{3}{*}{5} & & Import & 5 & - & 1 & 1 & 3 & $8 \times 10^{4 d}$ \\
\hline & & $\Omega$ & 5 & - & - & 2 & 3 & $8.3 \times 10^{4 * d}$ \\
\hline & \multicolumn{2}{|r|}{ All } & 50 & 6 & & & 19 & $4.1 \times 10^{4}$ \\
\hline
\end{tabular}

Kinds of cake with counts lower than the detection limits were not included in the calculation of the mean.

* Total APC using milk agar media. Means with the same letter are no differed significantly (0.05).

The imported packaged cake type (5) which is available in Egyptian market compared with that baked (types 1 and 2) and the locally packaged types ( 3 and 4 ) showed it had the highest APC values which was $8.3 \times 10^{4}$ CFU $\mathrm{g}^{-1}$ but in the safety limit (Table 3 ). This result was greatly astonished. It could be interpreted due to the filled cream and chocolate which are considered resources of contamination with microbes more than 


\section{Quality Of Some Types Of Cakes And The Economical Value}

the plain cakes. Same table showed that home-made cake (plain type) had the lowest APC, ranging from 1.0 to $1.3 \times 10^{4} \mathrm{CFU} \mathrm{g}^{-1}$ which agree well with those obtained in other study which reported that plain cake tended to have the lowest APC which was $\left(1.4 \times 10^{4}\right)^{(6)}$. The local commercial packaged cake powder (type 2) had more APC than the locally packaged ready to eat types $(3 \& 4)$ and also higher than similar results which worked on mesophilic bacteria only ${ }^{(26)}$. The mean of total aerobic bacteria count for all cake types analysed in the present study was $4.1 \times 10^{4} \mathrm{CFU}$ $\mathrm{g}^{-1}$ (table 3), which is approximately consistent with that previously revealed the APC for cake available in American markets was $3.4 \times 10^{4}$ $\mathrm{CFU} \mathrm{g}^{-1}{ }^{(27)}$. And other study stated that the mean APC of cake and biscuits available on American markets ranged from $10^{2}$ to $10^{4} \mathrm{CFU} \mathrm{g}^{-1}$ (27 \& 28). The low levels of microbial contents which were found in the local commercial packaged cakes either powdered type (2) or ready to eat types ( $3 \& 4)$, it could be attributed to the application of new decontamination technologies, sterilization, using anti-microbial agents as potassium sorbate in type (3) contents. Besides the packaging operation in the industrial process $(29,30 \& 31)$. Moreover, it was confirmed that the highest number of mesophiles and psychrophiles were detected in cream cake, while the lowest number of mesophiles and psychrophiles were detected in plain cake as stated in similar study ${ }^{(26)}$. Mean total count of fungi (log $\mathrm{CFU} / \mathrm{g}$ ) for the five cake types examined are in table (4). They were of satisfactory fungal quality. Total fungi counts were lower than the recommendation safety limit $\left(10^{3}\right)^{(22 \& 23)}$. There was a significant statistical result was observed between the five 


\section{Quality Of Some Types Of Cakes And The Economical Value}

cake types for total fungi which are found in the present study $\left(1.9 \times 10^{2} \mathrm{CFU} \mathrm{g}^{-1}\right)$. It is considerably higher than the total fungi reported in similar study was $\left(4.6 \times 10^{1} \mathrm{CFU} \mathrm{g}^{-1}\right)$ in cakes available in the American markets and other study made in Egyptian market reported the fungi content was ranged from 0 to $5 \times 10^{1}$ in unpacked and packed spongy cakes ${ }^{(26 \& 27)}$.

TABLE (4): TOTAL COUNT OF FUNGI EXHIBITED BY 25 SAMPLES OF THE FIVE CAKE TYPES

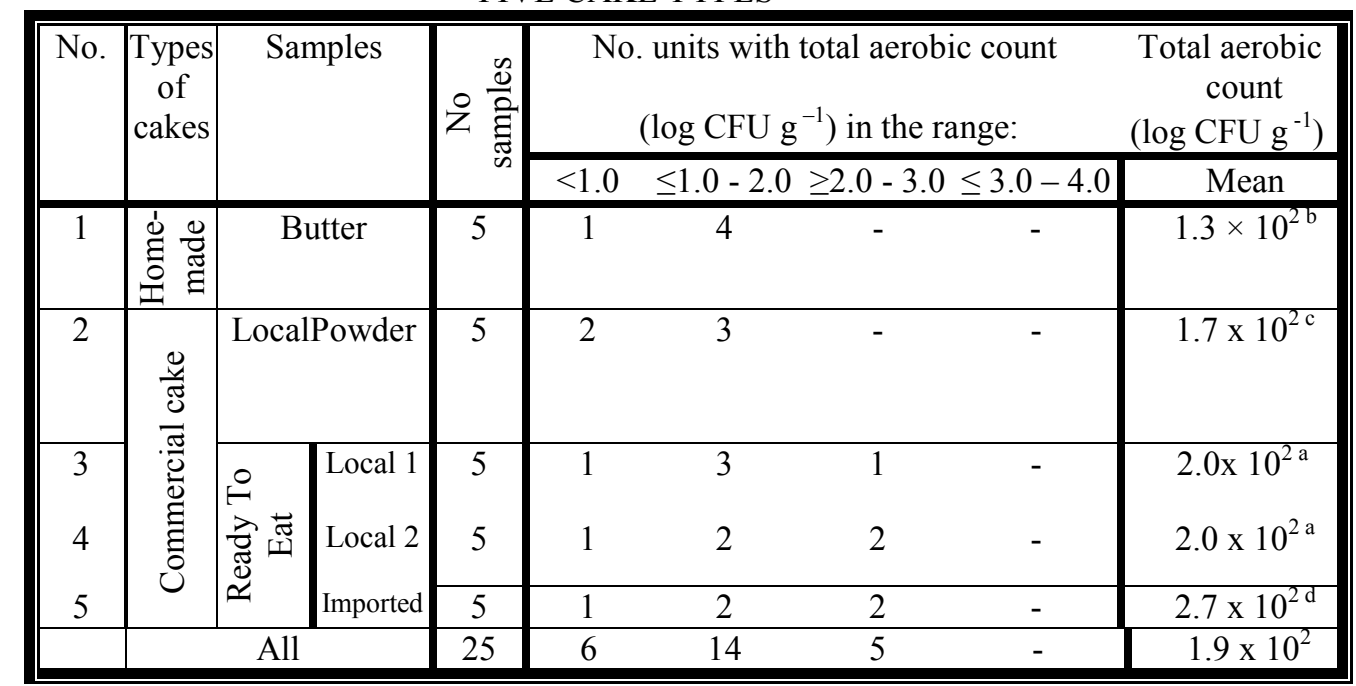

Kinds of cake with counts lower than the detection limits were not included in the calculation of the mean.

Means with the same letter are no differed significantly (0.05).

Table (5) represent the most common fungi spp. detected in the investigated five cake types were Aspergillus, with an incidence of over $40 \%$ of the cake samples, followed $20 \%$ for each of Rhizopus spp. and Alternia spp.. The present result was in complete agreement with the similar study indicated that moulds isolated from cakes were identified as 


\section{Quality Of Some Types Of Cakes And The Economical Value}

Aspergillus and Rhizopus, ${ }^{(32)}$. In other study Rhizopus spp. and Mucor spp. were isolated from commercial cakes available in Indian markets ${ }^{(33)}$. A good result in the present study revealed that total fungi count was lower than the recommended safety limits even the incidence of some species of fungi such as Aspergillus spp., Rhizopus spp. and Alternia spp. are still consider harmful marker depending upon the count number.

TABLE (5): ISOLATED TYPES OF FUNGI FROM THE FIVE CAKE TYPES

\begin{tabular}{|c|c|c|c|c|c|c|}
\hline \multicolumn{3}{|c|}{ Type } & Number & Aspergillus & Rhizopus & Alternia \\
\hline $\begin{array}{l}\text { Home- } \\
\text { made }\end{array}$ & \multicolumn{2}{|c|}{ Butter } & 5 & 2 & 3 & 1 \\
\hline \multirow{4}{*}{ 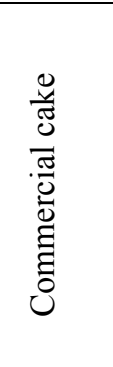 } & \multicolumn{2}{|c|}{$\begin{array}{c}\text { Local } \\
\text { Powdered }\end{array}$} & 5 & 4 & - & 1 \\
\hline & \multirow{3}{*}{ 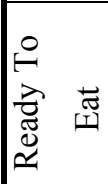 } & Local 1 & 1 & 1 & 1 & - \\
\hline & & Local 2 & 2 & 1 & 1 & - \\
\hline & & Imported & 1 & - & - & 3 \\
\hline \multicolumn{3}{|c|}{ All } & 25 & 10 & 5 & 5 \\
\hline \multicolumn{4}{|c|}{ percentage } & 40 & 20 & 20 \\
\hline
\end{tabular}

\section{Shelf Life And Sensory Evaluation During Storage}

According to the panel test for shelf life of baked cakes types $(1 \& 2)$ for acceptance and overall quality. Type (1) had the best sensory evaluation than type (2) in all categories. In the same time about $97 \%$ acceptability was obtained from the hedonic scale categoris at $\mathrm{P}=0.05$ showed that the shelf life study proved 3-5 days at room temperature $\left(25{ }^{\circ} \mathrm{C}\right)$ in summer, 5-8 days at $\left(20{ }^{\circ} \mathrm{C}\right)$ in winter. And 12-20 days on 


\section{Quality Of Some Types Of Cakes And The Economical Value}

refrigerator shelf in summer and winter respectively, and more than two months in freezer. After 70 days type (1) was the faster in spoilage symptoms than type (2) at room temperature due to the preservative in type ( 2 - the powdered). Our result was in contrast with that obtained which revealed that $100 \%$ of acceptability was obtained for the shelf life study performed on cakes packaged in poly propylene bags of 30 microns thickness indicated the shelf life of 13 days stated at room temperature $25{ }^{\circ} \mathrm{C}$ and $55-60 \%$ relative humidity. This could be translated to the additives were used which was (some types of fibers and nutrients) were supplemented plus the difference between the two environments ${ }^{(34)}$.

\section{The Economical Value And The Quality Of Cake Types:}

It's clear from table (1) that the cheapest was type (3) followed by types 1, 4, 2 and 5 the most expensive which equals twelve times as type (3) or six times as type (4) in price. Also, type (3) had the highest content from iron, type (4) had the highest content from protein after type (1). Both types $(3 \& 4)$ had the highest content of vitamin A. Beside the satisfactory level of microbiological analysis table (3, 4 \& 5) which indicated the hygienic precaution applied in Egyptian industry of cake.

It could be concluded that home made butter cake is the best. But the locally commercial packaged cakes (ready to eat) have many advantages. It showed the cheapest price, save effort, time and available in market. Besides it has more nutritive values and microbiologically safe compared with the most expensive (imported type), which is not better nutritionally 


\section{Quality Of Some Types Of Cakes And The Economical Value}

or microbiologically or economically. It could be recommended with Encouraging and trusting the local industry of packaged cakes (ready to eat) for saving money, effort and time. And consider cake as nutritious snack could fill the nutrient gaps between meals and satisfy the sweat taste for all age groups.

\section{Reference}

1- Hamid M. I., (1993). Utilization of Mandarin fruits for improving some bakery and beverage products. Egyptian J. Food Science, 21(1): 8795.

2- Cullen K. W., and Thompson D. I., (2005). Texas School Food Policy Change Related Middle School a la Carte/ Snack Bar Foods: Potential Saving in Kilocalories. J. Am. Dietet. ADA, 105 (12): 19521954.

3- Abdalla E. S. and Halaby M. S., (1998). Children and snacks. Bulletin of High Instit. of Public Health. Univ. Alex. 28 (2): 227-44.

4- Boeckner L., (1992). Nutrition for the school-aged child. University of Nebraska. Comperative Extension Education Programs. Dept. Agricul. USA.

5- Herman M. G., (1991). The ABCs of children's nutrition A sponsored message from the Am. Dietet. Assoc.

6- Khalafalla G. M., Zahra M. K., El-Shenawy M., Mohmoud O. S., (1991). Enterotoxin producing Staphylococci in some bakery products. Annals of Agricult. Science, Ain Shams -Univ., 36 (2):347-53.

7- Lunzina N. L., Stabrovskoya O. I., Iraganova T. B. and Zokusilarra G. N., (1986). Effect of pea protein concentrate on the microflora of dough and bread. Izvestia Vysshikh Uchebnykhz Avedenii Pishchevaya. Technologia No 1: 91-2. 


\section{Quality Of Some Types Of Cakes And The Economical Value}

8- American Dietetic Association (ADA), (1997). Position of the Am. Dietet. Assoc. Food and Water Safety. J. ADA. 97 (11): 184-89.

9- American Dietetic Association (ADA), (2003). Food and Water Safety. J. ADA. 103 (11): 1203-18.

10- Smith J. L., (1998). Food-borne illness in the elderly. J. Food Protect, $61: 1229-39$.

11- Sneed J., Strohbehn C., Gilmore S. A. and Mendonce A., (2004). Microbiological Evaluation of food service content surfaces in Low Assisted - living facilities. J. ADA., 104: 1722-24.

12- Saba N. H., (2003). Butter cake in, Cooking is art and science., eight th edition, Dar Elmaerf, Cairo, ARE. 698-700.

13- A.O.A.C., (1997), "Association of Official Analytical Chemists" Official Methods of Analysis of the Association of Analytical Chemists 990.08, Metals and other elements at trace levels in foods "published by the Association of Official Analytical Chemists, Washington, D.C. U.S.A.

14- Recommended Dietary Allowances (RDA), (1989). Food and nutrition board $10^{\text {th }}$ ed, National ResearchCouncil, Washington DC, p. 258. National Academy of sciences. National Research Council.

15- Monsen E., (2000). Dietary Reference Intakes (DRI) for the antioxidant nutrients: vitamin C, E, Selenium and carotenoids. J. Am. Diet. Assoc. 100(6): 637-640.

16- International Commission on Microbiological Specifications for Foods (ICMSF) Bulletin, (1987).. Microorganism in Food, Univ. of Toronto Press, Toronto and Buffalo, Canada.

17- Bibek R., (2001). Fundamental Food Microbiology, quality of bakery products, $2^{\text {nd }}$ edition, CRC press, UK; 423. 


\section{Quality Of Some Types Of Cakes And The Economical Value}

18- Kurtz, N. R., (1983). In "Introduction to social statistics" MC.GrowHill-Book Company, New York, USA. 163.

19- El-gedaily A. A. and Hemeada H. M., (2002). Food Evaluation: Scientific principles and standards. Arab Nile Group, Egypt. 1-69. (in Arabic).

20- Salama M. F., (2002). Effect of natural antioxidants on baking quality and stability of cakes. Egyptian J. of food Sci. 30 (2): 269-87.

21- Shaker A. M., Hammam A. H., Tawifik W. M. and Soliman A. Z. (2000). Updating Food Composition Table A Chemical Composition of Bread and Other Bakery Products. Bulletin of the Nutrition Instit. of Arab Republic of Egypt. 20 (1): 190-206.

22- International Dietetic Association of the European Community (IDAEC), (1999). Health and consumer protection directorate - general, Scientific committee of consumer, 063, 3-19. Belgium.

23- Egyptian Organization for Standardization and Quality Control, (2003). Cake, 4037.

24- Jin, M. N. Kejima, A. Arai, Y. Irikura, and Sakai S., (1984). Microbial contamination during manufacture in western style confectionary products. Ann. Rep Tokyo Metropolitan Res. Lab. Of Public Health 35: 256-63.

25- Mahmoud O. S., (1988). Microbiological studies on some bakery products with special reference to spoilage and food poisoning microorganisms M.SC. thesis. Faculty of Home Economics Monofia University, Egypt.

26- Gamal El-Din M. A., El- Sherif F. E., and Ragab SH. s., (1994). Microbiological profile of some bakery products (bread and spongy cake). Egyptian J. of Nutrition $8: 239-63$. 


\section{Quality Of Some Types Of Cakes And The Economical Value}

27- Swartzentruber A., Schwab A. H., Wentz B. A., Duran A. P. and Read R. B., (1984). Microbiological quality of biscuit dough snack cakes and soy protein meat extender. J. Food Protect.,47(6): 467-70.

28- Baylis C., MacPhee S., Robison A., Griffiths R., Lilley K. and Betts R., (2004). Survival of Escherichia coli O157:H7, O111:H- and $\mathrm{O} 26: \mathrm{H} 11$ in artificially contaminated chocolate and confectionery products. Int. J. Food Microbiol., Oct., 1 ;96(1):35-48.

29- Perial, M. Abu-Salem and Khalaf H. H., (1984), Nutritional and microbiological evaluation of some foods. Annals. Agric. Sci., Moshtohor, Egypt; 26, 2605-15.

30- Buzby J. C., (2002). Older adults at risk of complications from microbial food-borne illness. Food Re., 25 : 30-5.

31- Mc Cabe - Sellers B. J. and Beattle S. E., (2004). Food Safety: Emerging trends in food-borne illness surveillance and prevention J. Am. Dietet. Assoc., 104 (11) : 1708-17.

32- Fohrenhorst R.E. and Schulze N., (1998). Hygienic quality of whipped cream from automatic whipping apparatus. Arch. Fur Lebensmitted Hygiene 40 (3) : 67-71

33- Tamang $\mathbf{J}$ and Sarkar p., (2004). Microflora of murcha: an amylolytic fermentation starter. Microbe. ;81(327):115-22.

34- Wittig de pennea E., Avendano P., Soto D. and Bunger A., (2003). Chemical and sensory characterization of cakes enriched with dietary fiber and micronutrients for elderly, Arch Lationoen Nutr. Mar; 53(1): 74-83. 